\title{
Wetland conservation in Nepal: policies, practices, problems and possibilities
}

\author{
B.S. Poudel ${ }^{1}$
}

\begin{abstract}
Wetlands are among the most productive but threatened ecosystems on earth. Wetlands provide many benefits - environmental, economic and social - yet there is a limited assessment of these multiple values and therefore, have little attention in national accounts. Nepal has been transforming its resource management policies in favor of local people. This paper reviews existing policy framework and legal mechanisms involved in wetlands. There are several acts and regulations which have direct or indirect bearing on wetland conservation and management. It also discusses issues and possibilities of wetland management in Nepal. Finally, it recommends capacity building, wetland survey and inventory.
\end{abstract}

Key words: Wetlands, policies, plans, acts, Ramsar, ecosystem, values

W etlands ecosystems cover about $6 \%$ of the total global land area (Turner, 1991). They are considered to be one of the most threatened of all the major natural ecosystems and are argued to deserve a high priority for conservation. Invasion of alien species, unsustainable harvesting of wetlands and nearby ecosystem products, overgrazing, water and industrial pollution, excessive use of agrochemicals draining to nearby streams and discharge of industrial effluents are identified as major problems of wetlands.

Wetlands are crucial for human survival and economic well-being, for ecosystem functions and for earth's life support system. Wetlands are amongst the most productive life support systems on earth and are of immense socioeconomic importance by providing food, fodder, fuel and water for domestic, irrigation and industrial purposes (Kaul, 2003). They are critical for contributing to poverty reduction if managed and used properly.

Wetlands are valuable as services, sinks and transformers of a multitude of chemical, biological, and genetic materials. Wetlands are sometimes described as "the kidneys of the landscapes" because of the functions they perform in hydrologic and chemical cycles and as downstream receivers of wastes from both natural and human sources. They have found to clean polluted waters, prevent floods and recharge ground water aquifers (Anon, 2005).
Apart from these, now the wetlands are described as carbon dioxide sinks and climate stabilizers. Furthermore, wetlands are important because they help to curb soil erosion, lessen the impact of flood and drought, support fishing activity, and regulate the water cycle.

\section{Nepal's endeavor}

Nepal has demonstrated its commitment to wetlands conservation by signing the Ramsar Convention on December 17,1987 and by designating Koshi Tappu wetland in the Ramsar list. Since then, the Government of Nepal has initiated the move for protection and management of wetlands. Nepal presently has 9 sites designated as Wetlands of International Importance. These wetlands broadly represent high altitude, mid hills and lowland Terai wetlands. So far, a total of 34,455 ha area has been designated as Wetlands of International Importance in Nepal.

\section{Wetland related policies in Nepal}

Conservation and management of wetlands is reflected in various conservation policies of Nepal. National Conservation Strategy (1988) has emphasized the need for sustainable use of land and natural resources. The Master Plan for the Forestry Sector 1989, endorsed by Government of Nepal (1989), emphasizes the need to involve people in natural resources management. The Plan stressed

\footnotetext{
${ }^{1}$ Asst. Conservation Officer, Kanchenjungha Conservation Area, E-mail: bspoudel@dnpwc.gov.np
} 
Table 1: Wetlands of international importance in Nepal

\begin{tabular}{cclllll}
\hline SN & $\begin{array}{c}\text { Ramsar } \\
\text { Site No. }\end{array}$ & \multicolumn{1}{c}{ Name } & Location & $\begin{array}{c}\text { Date of } \\
\text { designation }\end{array}$ & $\begin{array}{c}\text { Area } \\
\text { (ha.) }\end{array}$ & $\begin{array}{c}\text { Elevation } \\
\text { (m asl) }\end{array}$ \\
\hline 1. & 380 & Koshi Tappu & Koshi & 17.12 .1987 & 17,500 & $75-81$ \\
2. & 1313 & Beeshazari and Associated Lakes & Chitwan & 13.08 .2003 & 3,200 & 286 \\
3. & 1314 & Ghodaghodi Lake Area & Kailali & 13.08 .2003 & 2,563 & 205 \\
4. & 1315 & Jagadishpur Reservoir & Kapilvastu & 13.08 .2003 & 225 & 197 \\
5. & 1692 & Gokyo and Associated Lakes & Solukhumbo & 23.09 .2007 & 7,770 & $4,700-5,000$ \\
6. & 1693 & Gosaikund and Associated Lakes & Rasuwa & 23.09 .2007 & 1,030 & $4,000-4,700$ \\
7. & 1694 & Phoksundo Lake & Dolpa & 23.09 .2007 & 494 & $3,611.5$ \\
8. & 1695 & Rara Lake & Mugu & 23.09 .2007 & 1,583 & 2,990 \\
9. & 1850 & Mai Pokhari & Ilam & 28.10 .2008 & 90 & 2,100 \\
\hline
\end{tabular}

that land and forest resources should be managed and utilized on a long-term basis so as to conserve the forests, soil, water, flora, fauna and scenic beauty. The Nepal Environmental Policy and Action Plan (1993) (NEPAP) has timely prioritized the need to identify and protect biologically significant marshes, wetlands, and water bodies. This Plan is an effective initiative for the protection of wetlands and provides a good policy foundation. NEPAP was further elaborated in 1998 (NEPAP - II) to address crosssectoral and sector plans which have identified fiftyfour environmental projects related, directly or indirectly, to the forestry sector that include wetland conservation programs. It states that wetlands in Nepal have often been overlooked as an important habitat type and that many wetlands are suffering from land and water pollution while others have been drained and converted to agricultural land. The Forestry Sector Policy (2000) stated that the soil, water, flora and fauna constitute the main elements of forestryn; nevertheless, it has been silent on wetland conservation.

Nepal Biodiversity Strategy (2002) explicitly addresses the wetland ecosystem. The strategy formulated a mixture of strategies to safeguard the wetland resources. It is the first government document that specifically catalogued and addressed wetland biodiversity and called for strategies to safeguard wetland habitats. Its implementation plan for 2006 has outlined integrated wetland management as priority projects (P-III) among the thirteen projects that will be implemented during the first phase of the plan (2006-2010) with the objective of developing integrated management plans at the watershed level to conserve wetland biodiversity and critical sites.

The Government of Nepal has endorsed National Wetland Policy 2003 with the objective of involving the local people in the management of Nepal's wetlands and to conserve wetlands biodiversity with the wise use of wetlands resources. The primary goal as stated in the policy is to conserve and manage wetlands resources wisely and in a sustainable way with local people's participation. Emphasis is given to conserving wetlands by involving the local people, promoting awareness, using wetland resources wisely, preventing and controlling pollution and invasive species. The policy directed the government - in consultation with concerned stakeholders - to formulate and implement integrated action plans that encourage multi-dimensional model and promote wetland conservation. The policy stated that the legal arrangements to make the wetland management activities effective should be formulated. The need to formulate acts, regulations and guidelines to ensure the jurisdiction and the capabilities of the bodies responsible for wetlands conservation and management is realized from all sides.

\section{Wetland related legislations in Nepal}

Nepal does not have a specific law that deals with wetlands but wetland management would come within the purview of several resource laws. There are several acts and regulations which have relevance to wetland conservation and management.

Wetlands are not defined as a separate category of ecologically important areas under National Parks and Wildlife Conservation Act 1973 and other resource laws like the Aquatic Animal Protection Act 1961, Soil and Watershed Conservation Act 1982, Water Resources Act 1992, Electricity Act 1992, Forest Act 1993, Environmental Protection Act 1996, Local Self Governance Act 1999 and the existing regulations under them.

Aquatic Animals Protection Act 1961 recognizes the value of wetlands and aquatic animals and identifies as offence activities to introduce poisonous, noxious or explosive materials into a water source or to 
destroy any dam, bridge, fish ladder, or water system with the intent of catching or killing aquatic life. National Parks and Wildlife Conservation Act 1973 prohibits blocking or diverting of any river, stream or other sources of water flowing into a national park or the introducing of any harmful or poisonous substance therein. The Act lists many mammals, birds and reptiles in its appendix as protected animals that are wholly or partially dependant on wetlands.

Soil and Watershed Conservation Act 1982 outlines the essential parameters necessary for the proper management of catchments areas, including rivers and lakes. It provides legislative measures concerning soil and watershed conservation to properly manage the catchments of Nepal. It also empowers the Government to declare any catchments area protected. Within the protected watershed the government could resettle, or relocate industries, businesses, and settlements. There is a long list of prohibited activities, such as clearing the forest, quarrying stone, soil and /or sand, interfering with water bodies, establishing industries, allowing livestock to graze etc. Water Resources Act 1992 strives to minimize environmental damage to wetlands, especially lakes and rivers, through environmental impact assessments. It states that the persons willing to make use of water resources for collective benefits on an institutional basis should form a water users association. Electricity Act 1992 prohibits blocking, diverting or placing hazardous or explosive materials in rivers, streams, or any water source. This Act states that there should not be any substantially adverse effect on environment by way of soil erosion, flood, landslide, or air pollution while carrying out electricity generation, transmission or distribution.

Forest Act 1993 defines ponds, lakes, rivers or streams and riverine lands within the Forest as national forest. This Act also empowers the government to declare any part of national forests as a protected area if the area has environmental, scientific and cultural significance. Environmental Protection Act 1996 stressed that nobody can generate pollution in such a manner as to cause significant adverse impacts on the environment or likely to be hazardous to public life and people's health. This Act directed authority to the Government of Nepal, by a notification in the Nepal Gazette, to declare any place within Nepal containing natural heritage or aesthetic, rare wildlife, biological diversity, plant, and places of historical and cultural importance, which are considered extremely important from the viewpoint of environment protection, as an environment protection area. It has made Initial Environmental Examinations or Environmental Impact Assessments mandatory for development proposals.

Local Self Governance Act, 1999, provides immense autonomy to the District Development Committees (DDCs), municipalities and Village Development Committees (VDCs) and they are required to plan and act for protection of forests, environment, and conservation of biodiversity. This Act lists out natural resources as property of the VDC and empowers VDC to levy taxes on the utilization of natural resources. Similarly, this Act sanctions the DDC to formulate and implement plans for conservation and utilization of forest, vegetation, biological diversity and soil. The Act allows DDC to bring to a halt environmentally unsound developmental projects.

\section{Problems and possibilities}

Legal and policy issues should include clear cut roles and responsibilities of local communities for the translation of National Wetland Policy provisions into actions through legislative measures. Technical issues include documentation of wetland related indigenous knowledge system, coordination among various public and private institutions, research and capacity building. Socio-economic issues include valuation, benefit sharing, investment and mobilization of financial resources, integration of poor peoples' choices and voices in wetland management. Ecological issues include building the understanding of ecological functioning and the application of ecological principles in decision making process. The current issues and future strategies of wetland conservation require a holistic view, keeping with the wise use of wetland resources for human welfare and economic upliftment as focal thrust areas.

Mid hills sites are of particular importance as this region represents only $0.26 \%$ of the total Ramsar area in Nepal. Addressing this gap and challenge requires declaration of more Ramsar sites in mid hills for ensuring comprehensive and stringent protection. Although the number of Ramsar sites has increased substantially since 2003 , there remain gaps in the protection given to these mid hill sites. This highlights the need for better target management for future sites. 
Regarding the management and wise use, indigenous peoples and local communities who live in areas adjacent to wetlands should have their rights respected by increasing their involvement in wetland management activities. Their relevant indigenous knowledge should be documented fully.

The most pressing issue for Nepal is poverty, which means that most resources are allocated towards education, employment, social welfare and development, with less allocated for conservation and wetlands. Certainly, more resources and new initiatives are needed. New and innovative approaches need to be applied to wetland management. Also, there should be increased financial investment in wetland management. Wetlands provide many benefits - environmental, economic and social - yet there is a limited assessment of these multiple values. Consequently, they are often not reflected in national decision making processes. Wetlands provide critical ecosystem services, which are undervalued by many public and private institutions and markets, but which need to be reflected in national accounts and the market place.

Rational conservation begins with the surveying and inventorying of resources, so a national inventory of wetlands in Nepal is needed. Yet to date, there is no national inventory of wetlands. Properly and timely formulated conservation plans followed by effective implementation strategy can lead to the sustainable use of our wetland (Karki and Chhetri, 2007). It is expected that once a number of future priority areas and project interventions have been agreed upon by all stakeholders, a more formal cooperation will need to be established.

Many organizations are working in wetland issues in Nepal but there is lack of coordination and synergy amongst them. Moreover, very few have specialist training and professional experience in the disciplines relevant to wetland management. Therefore, scientific and technical capacity of front line people involved in wetland management should be enhanced.

Despite some efforts in wetland conservation and management, integrated management planning of important wetlands are needed to translate policy into actions. These include programmatic approach to wetland management, institutional coordination and legislative measures

\section{Conclusions}

Government commitment to increase the coverage of Ramsar sites is essential. Moreover, success requires engaging local communities and developing a common vision. The Ramsar sites as well as nationally important wetland sites that lie outside the protected areas should be declared as environment protection areas and/or protected watersheds. The Government of Nepal has initiated the move for protection and management of wetlands. In an exemplary step, the Government has approved the National Wetland Policy 2003 that aims to involve local people in the management of wetlands and conserve wetlands biodiversity with the wise use of wetlands resources. Besides, the policy statements in Nepal Policy and Action Plan and Nepal Biodiversity Strategy specifically addressed wetland biodiversity and offered categorical strategies for their management. In Nepal, there is no one comprehensive legislation relating to wetlands but wetlands conservation comes within the purview of several laws.

\section{References}

Anon. 2005. Introduction to Wetlands. In Selected Readings on Wetlands and Coastal Habitat Management. Wildlife Institute of India, Dehradun, India.

HMGN. 1961. Aquatic Animal Protection Act 1961. His Majesty's Government of Nepal, Law Books Management Committee, Kathmandu, Nepal.

HMGN. 1973. National Parks and Wildlife Conservation Act 1973. His Majesty's Government of Nepal, Ministry of Forests and Soil Conservation, Kathmandu, Nepal.

HMGN. 1982. Soil and Watershed Conservation Act 1982. His Majesty's Government of Nepal, Ministry of Forests and Soil Conservation, Kathmandu, Nepal.

HMGN. 1988. National Conservation Strategy: Building on Success. His Majesty's Government of Nepal, Ministry of Forests and Soil Conservation, Kathmandu, Nepal.

HMGN. 1989. Master Plan for the Forestry Sector Nepal (Main Report). His Majesty's Government of Nepal, Ministry of Forests and Soil Conservation, Kathmandu, Nepal. 
HMGN. 1992a. Electricity Act 1992. His Majesty's Government of Nepal, Kathmandu, Nepal.

HMGN. 1992b. Water Resources Act 1992. His Majesty's Government of Nepal, Kathmandu, Nepal.

HMGN. 1993. Forest Act 1993. His Majesty's Government of Nepal, Law Books Management Committee, Kathmandu, Nepal.

HMGN. 1993. Nepal Environmental Policy and Action Plan 1993. His Majesty's Government of Nepal /Environment Protection Council, Kathmandu, Nepal.

HMGN. 1996. Environment Protection Act 1996. His Majesty's Government of Nepal, Ministry of Environment, Science and Technology, Kathmandu, Nepal.

HMGN. 1999. Local Self Governance Act 1999. His Majesty's Government of Nepal, Law Books Management Committee, Kathmandu, Nepal.

HMGN. 2000. Revised Forestry Sector Policy 2000. His Majesty's Government of Nepal, Ministry of Forests and Soil Conservation, Kathmandu, Nepal.
HMGN. 2002. Nepal Biodiversity Strategy 2002. His Majesty's Government of Nepal, Ministry of Forests and Soil Conservation, Kathmandu, Nepal.

HMGN. 2003. National Wetland Policy, 2003. His Majesty's Government of Nepal, Ministry of Forests and Soil Conservation, Kathmandu, Nepal.

GON. 2006. Nepal Biodiversity Strategy Implementation Plan 2006-2010. Government of Nepal, Ministry of Forests and Soil Conservation, Kathmandu, Nepal.

Karki, S and Chhetri, P.K., 2007, "Nepal's Wetlands: A Conservation Plan for Action" Workshop Proceeding by the Nepal River Conservation Trust (NRCT) and the Environmentalists' Association of Nepal (EAN).

Kaul, S. 2003. Wetland Conservation and Management: A National Perspective. In Chilika Vol. 4. Chilike Development Authority and Wetland International South Asia. Orissa, India.

Turner, K. 1991. Economics and Wetland Management. Ambio 20, 59-63. 